\title{
Production of Interprofessional Care for the Person with Oncological Disease: A Study on the Patient's Perspective
}

\author{
Rocío Andrea Cornejo Quintana ${ }^{1}$, Isabel Cristina dos Santos Souza ${ }^{2}$, Jéssica Miranda Pereira ${ }^{3}$, \\ Raphaella Alves Pires ${ }^{4}$, Raquel Stefanni Garcia Sales Lima ${ }^{5}$, Magno Conceição das Mercês ${ }^{6}$ and \\ Marcio Costa de Souza ${ }^{7 *}$ \\ ${ }^{1}$ Psychologist, Specialist in Oncology, Brazil \\ ${ }^{2}$ Social Worker, Specialist in Oncology, Brazil
}

${ }^{3}$ Pharmaceutical, Specialist in Oncology, Brazil

${ }^{4}$ Psychologist, Specialist in Oncology, Brazil

${ }^{5}$ Nutricionist, Specialist in Oncology, Brazil

${ }^{6}$ Assistant Professor, PhD in Heath Science,Brazil

${ }^{7}$ Assistant Professor, PhD in Human Medicine and Health, Brazil

**Corresponding author: Marcio Costa de Souza, Assistant Professor, PhD in Human Medicine and Health, Brazil

\section{ARTICLE INFO}

Received: 慧 July 27, 2020

Published: 幽 August 07, 2020

Citation: Rocío Andrea Cornejo Quintana, Isabel Cristina dos Santos Souza, Jéssica Miranda Pereira, Raphaella Alves Pires, Raquel Stefanni Garcia Sales Lima, Magno Conceição das Mercês, Marcio Costa de Souza. Production of Interprofessional Care for the Person with Oncological Disease: A Study on the Patient's Perspective. Biomed J Sci \& Tech Res 29(3)-2020. BJSTR. MS.ID.004797.

\section{ABSTRACT}

Introduction: This study aimed to analyze the perception of people with Oncological diseases about interprofessional care, in a public hospital in Salvador de Bahia - Brazil. It was adopted a phenomenological qualitative research approach, in which a semi-structured interview, a field log and medical records were used. Also, fourteen patients hospitalized participated in the study.

Development: Through the Analysis of the interviews, there were identified categories of meaning linked to humaninteraction, such as the team-patient relationship, affective work, live care network and negative impacts of interprofessional care.

Conclusion: It was observed the primary role that Oncology patients gave to human contact with the team, so it is essential that the interprofessional team pay attention of the subjectivity and feelings of the patient, at the moment of meeting and during the assistance to them. Measures could be taken, considering humanized care.

Keywords: Interprofessional Care; Oncology ; Health; Cancer

\section{Introduction}

The concept of Care refers to all actions and interventions that aim to restore or generate autonomy, hope, freedom of choice, human relations, and the meaning of life. The production of care refers to the daily life, the place of events, manifestations, details, and situations, related to the dimension of details that are part of life [1]. Care is bound to an inexhaustible integrality, since it will always be possible to add new aspects of the subject's existence, and it will only be possible to exist in front of an intersubjective flow, in which people, instrumented with certain human knowledge and qualities, get close to each other [2]. Considering that the subject in need of care is a human being in its corporal and subjective comprehensiveness, interprofessional teamwork becomes essential in order to consider the completeness of the individual for care production in the hospital environment. In this way, nutritionists, 
psychologists, nurses, social workers, doctors, pharmacists, and other professionals, must act as a team to consider the subject as a whole, so that he can have access to humanized actions which contemplate all his needs [3].

Regarding Oncology Care, this type of care is linked to the complexity and severity of this disease since the person with cancer needs to be treated with highly specialized techniques. At this point, the patient is at risk of having a significant emotional impact, mood swings, psychic and physical suffering, and thoughts about the finitude of life [4]. When dealing with hospitalization for neoplasms in Brazil, in 2016, 767,954 hospitalizations were conferred and in Bahia 46,958 [5]. The neoplasia proper and the complications resulting from cancer treatment make hospitalizations frequent and prolonged, causing the patient to suffer feelings of suffering and forsakenness [6]. This course of illness causes cancer patient care to have a connotation directed at the concept of integral healthcare, within which the team and patient should be active participants [7]. Nevertheless, it can be perceived that there is a paucity of studies that address the patient's perception of interprofessional care. Due to these issues, this research aimed to analyze the perception of people with Oncological diseases about interprofessional care in a large hospital in Salvador, Bahia, Brazil.

\section{Method}

This study was developed through a qualitative exploratory and phenomenological approach. The study participants were patients with an oncologic disease, hospitalized for at least 5 days. The number of participants was defined by the saturation criterion of the answers, totaling 14 participants. The study setting was an oncology center of the public health system (SUS) of a large philanthropic hospital in the city of Salvador, Brazil. In addition to the various specialties in the health field, this hospital also acts as a High Complexity Oncology Unit (UNACON) in the state of Bahia. On the production of data, we used a semi-structured interview, which aims to capture the subjects' point of view, leaving the researcher and participants of the study free to discuss the proposed theme [8]. As guideline for the interview, a semi-structured script was developed and divided into four topics: Identification of the health care team; Perception of the function of each professional mentioned in the previous item; Perception of the interaction between health professionals and the communication of the interprofessional team with the patient and; Benefits/losses in the care relations between the health team/patient.

During the interviews, a tape recorder (Motorola G3) was used as a way of guaranteeing the trustworthiness of the testimonies, with due secrecy, thus recording questions and answers. Also, a field diary was used, which was elaborated by the researcher during the course of the study, following the semi-structured interview script guidelines. Finally, the documentary analysis became fundamental as a tool to complement the production of data, in which the medical records of the users were used. For the data collection, an active search of the profile of the hospitalized patients was done via medical records and afterwards the viability of the interview was discussed with the health team. Concerning this, contact with the hospitalized people was initiated, the research was presented and they were invited to participate. The term of free and informed consent was also presented, emphasizing the guarantee of anonymity and free choice to leave the research at any time. After the participants' consent, the researcher read aloud each question from the semi-structured interview and left a reading copy for the patient. After the response was issued, the following question was asked, in a comfortable place.

The data analysis method was the Institutional Analysis of Lourau [9] which understands the field as something inherent to the researcher, inseparable; therefore, there is an intersection of implications for all who are involved in this search. Thus, it is necessary to map the existential territories before the sights and situations placed in the reality of the working world. In order to systematize the data for their analysis, the following steps were performed: the data was initially ordered by mapping all the obtained information (transcription of the recordings, re-reading of the material, organization of the recordings, the data of the field diary, and the documentary sources). Therefore, the classification of the data and the identification of analyzers was carried out and the empirical categories - which were identified through exhaustive reading - of the collected information were elaborated. Finally, empirical data was coupled with the theoretical references of the research and documents, thus promoting a relationship between concrete and abstract, general, and singular, theory and practice.

\section{Results and Discussion}

In this research we had 14 participants. Of them, 8 were males and 6 females; 8 stated to be married and 6 were single; 9 came from Salvador and 5 from the countryside of the state of Bahia; 4 followed an oncological treatment with no possibility of cure and 3 palliative Care as main treatment. We identified several meanings of interprofessional care production from the patients' perspective through the spontaneous speech of the participants. Within these, the implications of the care relationships and the ways of care and communication between patient-staff and vice versa were highlighted, emphasizing the quality of these interactions, which had a significant influence on the care processes with the oncological patient.

\section{Team-User Relationship}

In this meaning, we highlighted the relevance that some participants gave to the construction of a relationship between the health team and the cancer patient, thinking of it as a health promotion device. The relationship between team and user is functional and healthy when the team is able to perceive the person with cancer as a unique individual, confirming their existence as a human being [10]. By the statements of interviewees 6 and 7 it can be noticed that they reported the presence of the relationship as 
part of the production of care between the patient and the heath team:

They talk with us, talk, pay attention, sometimes they play. Yes, they play, and then we forget the problems that we are feeling, right?! Then the pain that we are feeling are going away the psychologist, always, she is always there, every day, right? Every day she has to see me, she worries about me, and my doctor also.

welcomed by everyone, everyone treats me well no one has ever treated me wrong neither when I call look, there is something here wait, I come back in a moment, quickly they come back I got it. I will talk, they come I will be back I go and come back here and fix it right away without discretion. One is well treated and treat the other well all the same.

The discourse of these interviewees showed a notion of functionality on the team-patient relationship, in which both parts were participants. That is, individuals with cancer disease were able to express themselves as human beings with feelings and needs, and in return, being listened to and welcomed by health professionals. In the day-to-day life of the oncologic ward, it was noticed that patients asked and talked more if they were more involved in their own treatment when they were recognized as individuals by the interprofessional team. A simple "Hello, good morning, how are you?" on the part of the team, listening to the patient, made the difference for the patient to feel more at ease and often even happy, creating a relationship of trust with the professionals. A study about those human interactions [11] indicated that cancer patients revealed their desire to be recognized as individuals by the health professionals, characterizing a relationship as functional when the professionals made eye contact with them, sitting down and remembering their names instead of just standing there by their side. Other studies pointed out that the notion of oncology care could be fulfilled when a relationship between the health team and the patient exists. Therefore, the team needed to be open to the possibility of relating to them, to be available in that relationship, attentive and empathetic, identifying the desires and needs of those being cared for [10-13].

On the other hand, two interviewees brought the notion of what a non-functional relationship would be if it happened:

The loss would be mistrust, not being sure of what I am doing, which way I am walking, where I'm going, right? What direction am I taking? If there was no such interaction, I would not know the direction I am taking in this treatment. According to that interviewee, mistrust could reach him as a symptom of malaise in the meeting with the interprofessional team, generating doubts and uncertainties regarding his care. Through the experience with some patients it can be noticed that the distrust tended to increase when the health team didn't include the patient as a participant in the planning of their own treatment, not giving space to express themselves, thus opening a breach for fantasies and unanswered questions. According to Orlandi [14], when a being meets another, they are predisposed to be in a subjective condition of alertness, aiming to achieve in this meeting what they evaluate as beneficial to their health. However, due to this expectation, it is to be expected that they could experience well-being or malaise, symptoms of trust and/or distrust, depending on each situation in their singular feeling. Given the complexity of human subjectivity, it is up to the interprofessional staff to be attentive to the feeling of trust or distrust in the interaction with the person with cancer, aiming to reduce the disturbances that may generate distrust in the quality of care.

\section{Affective Work}

Affective work is one of the lines of care that belongs to the integral assistance with the patient, regarding immaterial work. That is, affective work produces immaterial health effects, such as feelings, sensation of well-being, knowledge, among others [15]. In the intersubjective meeting with the patient, affective work has the capacity of interaction through emerging affections, where the health worker perceives himself and feels the other, building a fluid care relationship produced through the meetings between health workers and patients [16].

Well, because when the doctor arrives with small talk... when the doctor arrives and treats well, he gives a little life or many years of life to us, when he treats well, he gives years of life, many years for us. When he treats poorly (non-verbal expression of cutting with the hand*) he kills, kills us. And the ones here, they treat us very well I do not say the person, I do not say the person, talking to the doctor, they treat us well, know how to laugh, play, "how are you? How are you?" With their heart full of love

ah, generally well. I do not worry. Attention to the patient, love for the patient, respect for the patient, dedication to the patient. So, the doctor, picking up the client and giving love, affection, spirit, makes the patient feel loved. Some nurses have an excellent level

Those patients denoted the presence and importance of affection in the health team's work, as a tool that generated life and love. When the worker is in body and soul in his relationship with the other, aware of the influence of his affections in this encounter, the profits could be perceived, because the patients tend to manifest the benefits of the presence of affective work. In the hospital routine of the researchers, more than once the scene of some patient praising the affective work of a professional had been witnessed, highlighting how feeling welcomed and loved was a health generator to them. This not only contributed to the mood of the patient, but to the production of care. Franco and Merhy [17] indicated that one of the main potential questions of affective work was its capacity to produce life, an issue that is a part of the main goal of any interprofessional health team, making the presence of affective work coherent in their professional practices. Still, the interviewees highlighted the immaterial results that were being developed in the meeting with the team, pointing out that that aspect was being worked properly, provoking in them a 
sense of well-being. On the other hand, interviewee 1 brought the destructive capacity that inadequate affective care can bring when it is permeated by indifference. Thinking about this, the meaning of care involving indifference was found in other interviews

There are nurses there are also people who destroy, but that is very natural, people who are out of tune, there is no way. A person out of tune is, that hurt, disheartened, closed heart person.

Oh, with me everything is fine. I keep quiet if they come in and say something. Sometimes they pass sulky and I do not know why, then I have to take it because they are angry? I am not, I am not going to make such a move. Then the person arrives "everything fine mister XX?", I answer "everything".

Those interviewees alluded to the absence of affective work, where the professionals take care without perceiving the subjectivity and needs of the patient, which can cause unwanted effects in the care, such as communication noises, dysfunctional feelings, breakdown in the patient-team bond and even the sensation of "dying". Thinking about this, those difficulties (not looking at patients, not presenting themselves, treating them inappropriately, emitting feelings that do not fit with a professional health environment, such as anger or disgust) often could bring immeasurable damages to those being cared of. Merhy and collaborators [18] indicated that when the professional was not really present in the meeting with the patient, acting in a protocolized way, canceling the subjective difference of the person in need of care, eventually the possibilities of dialogue between patient-team might be reduced, decreasing the patient's chance of using the care that the team can offer.

\section{Live Network}

The concept of a living network came from the moment when no one cannot longer think about health in a linear way, since thinking about health production involves several actors and systems, constantly influencing themselves in a complex network of care [19]. Therewith, thinking about health is considering the constant interaction between patient, family, team, infrastructure, relationships, frictions, affections, supra- and subsystems.

The techniques. So that is fantastic, because you know to who it is directed. "My name is so-and-so and I will be staying with you, you and you" so then she is your bridge of support and the connection to the rest. Let us say, if by chance... I know that it is not the time to clean the bathroom, but the bathroom is vomited, then you say, "ah but the bathroom is like that" and incredible as it seems she goes, you understood? Oh, she goes there, she sorts of... reverses the... depending on the case. Then she arrives with the cleaning and exchange people, the mediation of the communication, that is perfect

I say, "I'm at the square" and she says "Hi! There is medication", but she has no obligation, is not part of hers. If she does it by herself because as a patient you know you have the rules to follow as well.
You know you have medication, you know you have to be on the bed. Right? I know I can come and go, but not like I do, I spend all afternoon sitting, and "do you have medication for me?" "not only be at the end of the day" So it is up to me to be here and not to her to call me, understand? So that is, I think it is an extra affection.

That we complain, but what is good, is to send the message back, right? Then I sent for her and I talked to the nurse, to send to the kitchen staff. I think it is. What the... that is useful, right? I do not know, what I told you. I cannot tell if they are overworked or not, I do not know, but uhh, I think it works.

That interviewee brought several aspects that coincided with the construction of a living network of care, which seemed to be a part of the processes of care for her. Those statements emphasized the importance of effective individual-team and interprofessional communication and interaction, resulting in positive effects on her overall health. In addition, she placed herself as an active and responsible element in the care for herself and others, because she remained as an active participant in the procedures and still payed attention to the subjectivity of the health professional, thus building a relationship of mutual care. All those thoughts and actions were parts of her construction of health reality, constituting a network of care. During the routine of the studied ward, the live network was seen in a shy manner, probably due to the different rules that surrounded the hospital environment, which often cause both the team and the patient not even able to think about the fluidity of care activities. On the other hand, when the network was sighted, care becomed dynamic, creative, uniting professionals and patients pursuing health.

Thinking about the possibility of dynamism in health care, that interviewee stated the ability of some professionals who had left the conventional care protocols to promote health, an action that she called "unexpected". This activity is called by several authors as living work $[19,20]$, in which professionals have the opportunity to develop a free-activity, in the sense of allowing the construction of personalized health processes, unique to each professional, creative, giving openness to the subjectivity and individuality of all actors in the process.

\section{Negative Impacts on Care}

Regarding Bioethics applied to healthcare [21], negative attitudes to oncological care can be considered as those attitudes and procedures that damage the principles of autonomy, beneficence, non-maleficence, and justice. Although most of the interviewees did not mention negative impacts in their care experience, some of the subjects exposed the following experiences.

She came in here, did not say good night to anyone and the second time also the same thing.

It bothered me because everyone was awake. No, why does she enter here as if there were, that there was no one, as a dog, you understand? 
Then I called a person an hour later I did not want to keep calling. Oh, "what does this woman want?" I got it, I asked. To be it is, it is. Because she ran her hand, it was dirty with feces, then the girl came and I said, "can you change it?" and it took her a while to change me.

There was a doctor who told me I was not going to take chemo, so that harmed me [...] that the drugs were going to be thrown away. That it would be useless. For me it was a moment of sadness... that I thought it would be no use fighting for anything else. Only God was going to fight for me.

I was on one side, with feces, she asked me to get up and sit down... it embarrassed me, I even got cry. It was such a disrespect, so disrespectful of her. I went to the infirmary to report that I had a hygiene problem and "look at this old man, he doesn't get up to go to the toilet". I had to hire a person, because this was not possible, every day to come to take care of me, accompany me, so as not to feel bad. So, whoever, whatever class, must be respected.

The interviewees mentioned above were in extended hospitalization for more than twenty days and their oncology treatments were made jointly with the palliative care team. Regarding this, respect for the patient is fundamental, since it is not possible for the health team fully understand the subjective experiences of the patients, it is noticed that the patient with an oncological disease is going through a difficult time. Within the characterization of oncological patients who need palliative care [22], it is known that they require an intensification of technical procedures that aim the relief of symptoms and care of bio-psychosocio-spiritual aspects.

Thinking about the bias of the "Health Technologies" mentioned by Franco and Merhy [17], the technologies that should be strengthened in this context are the so-called "light-hard" and "light" technologies. In "light-hard" technologies, the team would focus on technical knowledge, effective communication on the treatment, flow of procedures and decision making. "Light" technologies, on the other hand, lay the emphasis on the professional-individual relationship, considering the creation of bonds of trust and affectivity, fundamental attributions for palliative care workers [23]. Given what was said by the participants, it can be seen that the care that was being provided was not related to their needs, which was a failure in the exercise of bioethics and in the execution of technologies, such as not identifying the need of technical procedures, inadequate communication and lack of perception of the subjectivity in the relationship with the patient. The patients even mention feelings of "embarrassment", "sadness" and "disrespect" in the interaction with the health team members.

Those situations have a common point, in which subjective care surrounds. This way of care stands out because it is a humanized and integral act based on political action and ethics, passing through technique, that produce new possibilities of feelings. However, in the experience of those people, this format of care production is not being offered in their daily lives. As a reflection regarding negative impacts, participant 9 said when someone works with dedication, well even with their problems, they work naturally, better, they do it better, faster, more dedicated. When you do not bury your problems, you tell others, it creates problems for them and for the patient. We highlighted the perception of the interviewee on how the subjectivity of the worker himself influences the way on how he will care the patient. On this influence, Pfaff [24] indicated that the empathy that the interprofessional team can offer in contact with the person with an oncological disease starts to reduce when they are exposed to psychic suffering. This can be alleviated from the professionals' ability to perceive themselves, exercise selfcontrol, as well as hospitals' actions that aim at the promotion of the workers' health in this context. By analyzing the interviewee's utterance, we interpreted it as an invitation to the self-reflection of each health team member. A call to self-perception, aiming the mental health of the worker himself as something to be taken care of, for their sake and consequently the sake of the patient. Thus, ideally, actions that offer health and well-being for all who are involved in the process should always be constructed.

\section{Final Considerations}

In view of the variety of meanings that can be attributed to the process of interprofessional health care, this study found the leading role that patients attribute to the human contact with the team, the positive connotation to the moment when the professional built a singular and creative care relationship with them, in which both can expose their subjectivities through the smallest gestures of everyday life, feelings and affections, thus conforming what we can call care. However, it can be seen that the desired care was not always provided, identifying discrepancies in the approaches of the different members of the interprofessional team, observing moments of depersonalization and disqualification of the subject. Within health technologies, it is noticed how the light technologies play a fundamental role in the integral and humanized care of the person with an oncological condition, and in this research, it stands out clearly. The moment of the health-worker/patient meeting can produce life or discomfort, which will depend on how the meeting participants interact and affect each other. Therefore, the interprofessional team has a duty to be alert to the subjectivity and the processes of subjectivation of the patient, and more than that, be aware that their contact with the individual is a generator of subjectivity and health. In this perspective, the reflection on strategies that can establish forms of care that meet the health needs and the way in which the health and disease process is thought, has provoked a (re)thinking of the operational protocols and the educational actions within the Brazilian health units, in order to equip the team regarding the meaning of the production of subjective care linked to the technical treatment in Oncology. However, perhaps the most basic changes that could be made to 
achieve integral health should begin with a new look at the training of the health workers and the construction of spaces of ongoing education, in which the logic of the work process should be based on micropolicies. This could strengthen attitudinal competencies in caring for and operating with potency and quality in the daily life of people who have an oncological disease. This study showed the possibility to bring perspectives of the care production in Oncology. However, the elaboration of studies aiming to reach the perception of several focus groups that participate of this context, whether health workers, support team members, family, among others, may be of high relevance.

\section{References}

1. Ray MA (2016) Theoretical and transcultural Caring Dynamics in nursing and Health Care. Transcultural Caring Dynamics in Nursing and Health Care. In Ray MA (Eds.), (2 ${ }^{\text {nd }}$ edn.), Philadelphia FA Davis pp. 3-34.

2. Martines WRV, Machado AL (2010) Produção de Cuidado e Subjetividade. Rev. brasileira de Enfermagem, Brasília 63(2): 328-333.

3. Schmitz C, Atzeni G, Berchtold P (2017) Challenges in interprofessionalism in Swiss health care: the practice of successful interprofessional collaboration as experienced by professionals. Swiss Medical Weekly. 147: w14525.

4. Peçanha DLN (2008) Câncer: Recursos de enfrentamento na trajetória da doença. In: Carvalho, V. A. et al. (Org.). Temas em psico-oncologia pp. 209-217.

5. (2017) DATASUS Ministério da Saúde. Sistema de Informações Hospitalares do SUS (SIH/SUS). Retrieved from: http://tabnet.datasus. gov.br/cgi/deftohtm.exe?sih/cnv/niuf.def.

6. Frade M, Lopes M (2016) Estratégias adotadas pelo familiar cuidador da pessoa com doença oncológica em tratamento por quimioterapia no processo de aquisição de competências. ENF - Comunicações Universidade de Évora. $10^{\text {th }}$ International Seminar of Nursing Research. Universidade Católica Portuguesa.

7. Bilodeau K, Dubois S, Pepin J (2015) The care continuum with interprofessional oncology teams: Perspectives of patients and family. Canadian Oncology Nursing Journal 25(1): 30-36.

8. Minayo MCS (2013) O desafio do conhecimento: Pesquisa Qualitativa em Saúde. 13.ed.São Paulo - Hucitec.

9. Rossi A, Passos E (2014) Análise institucional: revisão conceitual e nuances da pesquisa-intervenção no Brasil. Revista EPOS 5(1): 156-181.

10. Ashcroft J, Childs R, Myers A, Schluter M (2016) Multiplexity: Context for Breadth. In: The Relational Lens: Understanding, Managing and Measuring Stakeholder Relationships. Cambridge: Cambridge University Press pp. 74-92.

ISSN: 2574-1241

DOI: $10.26717 /$ BJSTR.2020.29.004797

Marcio Costa de Souza. Biomed J Sci \& Tech Res

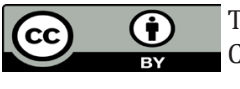

This work is licensed under Creative Commons Attribution 4.0 License

Submission Link: https://biomedres.us/submit-manuscript.php
11. Thorne SE, Kuo M, Armstrong EA, Mcpherson G, Harris SR (2005) 'Being known': patients' perspectives of the dynamics of human connection in cancer care. Psycho-Oncology 14(10): 887-898.

12. Ekwall E, Ternestedt BM, Sorbe B, Graneheim U (2011) Patients perceptions of communication with the health care team during chemotherapy for the first recurrence of ovarian cancer. European Journal of Oncology Nursing 15(1): 5-58.

13. Barros A (2014) Processo de cuidar de um centro de tratamento oncológico. Natal: Universidade Federal do Rio Grande do Norte.

14. Orlandi LBL (2010) A respeito de confiança e desconfiança. In Franco.T.B \& Ramos, VC(Org). Semiótica, Afecção \& Cuidado em Saúde São Paulo: Hucitec pp. 17-34.

15. Mansano SRV (2014) 0 trabalho imaterial afetivo na área da saúde. Perspectivas en Psicología 11(1): 86-92.

16. Fonseca MLG, Sá MC (2015) A insustentável leveza do trabalho em saúde: excessos e invisibilidade no trabalho da enfermagem em oncologia. Saúde debate 39 (spe): 298-306.

17. Franco TB, Merhy EE (2012) Cartografias do Trabalho e Cuidado em Saúde. Tempus - Actas de Saúde Coletiva.

18. Merhy EE, Feuerwerker LCM, Cerqueira MP (2016) Da repetição a diferença: construindo sentidos com o outro no mundo do cuidado. In Feuerwerker LCM, Bertussi DC Merhy EE (Eds.), Avaliação compartilhada do cuidado em saúde: surpreendendo o instituído - Livro Rio de janeiro: Hexis pp. 60-75.

19. Franco TB (2013) As Redes na Micropolítica do Processo de Trabalho em Saúde. In Franco TB, Merhy EE(Eds.), Trabalho, produção do cuidado e subjetividade em saúde. Hucitec Editora, Rio de Janeiro pp. 188-203.

20. Merhy EE (2015) Educação Permanente em Movimento - uma política de reconhecimento e cooperação, ativando os encontros do cotidiano no mundo do trabalho em saúde, questões para os gestores, trabalhadores e quem mais quiser se ver nisso. Saúde em Redes 1(1): 7-14.

21. Ebbesen M (2016) Bioethics across Cultures - Philosophical and Empirical Justification of the Four Principles of Biomedical Ethics. J Clin Res Bioeth. 7(1): 1-3.

22. Matsumoto DY (2012) Cuidados Paliativos: conceito, fundamentos e princípios. In: Carvalho RT, Parsons HA. (Org.) Manual de Cuidados Paliativos. São Paulo: Academia Nacional de Cuidados Paliativos (ANCP); pp. 23-30.

23. Theobald MR, Santos MLM, Andrade SMO, De Carli AD (2016) Percepções do paciente oncológico sobre o cuidado. Physis 26 (4): 1249-1269.

24. Pfaff KA, Freeman gibb L, Patrick LJ, Dibiase R, Moretti O (2017) Reducing the "cost of caring" in cancer care: Evaluation of a pilot interprofessional compassion fatigue resiliency program. Journal of Interprofessional Care. 31(4): 512-519. 